\title{
Tinjauan Kebijakan Keuangan Publik menurut Abu Ubaid dalam Kitab Al Amwal terhadap Pengelolaan Dana Ta'zir di BRI Syariah KCI Citarum Kota Bandung
}

\author{
Firyal Nada Zakiyah Zaini Abdul Malik Eva Misfah Bayuni \\ Program Studi Hukum Ekonomi Syariah, Fakultas Syariah, Universitas Islam Bandung \\ Jl. Tamansari No. 140116 \\ firyalnadha@gmail.com, za.abuhibban@gmail.com, evambayuni@gmail.com
}

\begin{abstract}
Abstarct-Management of ta'zir funds in sharia banking financial institutions including BRI Syariah still lacks clarity in its allocation. Because ta'zir funds which are non-halal income funds are combined with ZIS social funds allocated for CSR activities held by BRI Syariah. Related to this, the scholars have inherited the concept of thinking regarding the allocation of sources of public financial funds, including ta'zir, which is distinguished by the income of other public financial resources such as zakat, taxes, customs and others. One of the scholars who had the concept of public financial management policy was Abu Ubaid through his omniscience, namely the book of Al Amwal. Thus, the purpose of this study is to know the review of the concept of public financial policy according to Abu Ubaid in Kitab Al Amwal on ta'zir fund management at BRI Syariah KCI Citarum, Bandung. The research method in this paper uses descriptive analysis method by describing ta'zir fund management in the BRI Syariah KCI Citarum according to the concept of ta'zir fund management according to Abu Ubaid in the book of Al Amwal. The results of this study indicate that the management of ta'zir funds at BRI Syarriah KCI Citarum Bandung has not been fully in accordance with the concept of management of tazir funds according to Abu Ubaid in the book Al Amwaal.
\end{abstract} Bank.

Keywords-Ta'zir, Management, finance and Islamic

Abstraks-Pengelolaan dana ta'zir di lembaga keuangan perbankan syariah termasuk BRI Syariah masih belum memiliki kejelasan dalam pengalokasiannya. Karena dana ta'zir yang merupakan dana pendapatan non halal tersebut disatukan dengan dana sosial ZIS yang dialokasikan untuk kegiatan CSR yang diselenggarakan BRI Syariah. Terkait hal tersebut, para ulama telah mewariskan konsep pemikirannya mengenai alokasi sumber dana keuangan public termasuk ta'zir yang dibedakan dengan pendapatan sumber dana keuangan public yang lain seperti zakat, pajak, bea cukai dan lain-lain. Salah satu ulama yang memiliki konsep kebijakan pengelolaan keuangan public adalah Abu Ubaid melalui mahakaryannya yaitu kitab Al Amwal. Dengan demikian, maka tujuan penelitian ini adalah untuk mengertahui tinjauan konsep kebijakan keuangan publik menurut Abu Ubaid Dalam Kitab Al Amwal terhadap pengelolaan dana ta'zir di BRI Syariah KCI Citarum Kota Bandung. Metode penelitian dalam penulisan ini menggunakan metode deskriptif analisis dengan mendeskripsikan pengelolaan dana ta'zir di BRI Syariah KCI Citarum ditinjau menurut konsep pengelolaan dana ta'zir menurut Abu Ubaid dalam kitab Al Amwal. Hasil dari penelitian ini menunjukkan bahwa Pengelolaan dana ta'zir di BRI Syarriah KCI Citarum Bandung belum sepenuhnya sesuai dengan konsep pengelolaan dana tazir menurut Abu Ubaid dalam kitab Al Amwaal. Syariah.

Kata Kunci: - Ta'zir, Pengelolaan, keuangan dan Bank

\section{PENDAHULUAN}

\section{A. Latar Belakang Masalah}

Penyaluran pembiayaan yang dilakukan oleh bank syariah tidak semuanya dapat berjalan dengan baik karena penyaluran pembiayaan tersebut memiliki tingkat risiko tersenriri. Dalam pelaksanaanya, terkadang bank mengalami pembiayaan bermasalah (non performing finance) yaitu kondisi dimaa pihak nasabah tidak membayar piutang pembiayaan atau gagal bayar sesuai dengan kesepakatan akad. Gagal bayar atau wanprestasi merupakan risiko yang dialami bank syariah dalam melakukan pembiayaan yang dimana risiko tersebut harus diminimalisir demi mendapatkan keuntungan yang maksimal. Akibat dari wanprestasi itu biasanya dapat dikenakan ta'zir (denda), pembatalan kontrak, peralihan resiko, maupun membayar biaya perkaranya.

Dasar hukum pemberlakukan ta'zir salah satunya merujuk pada ketentuan Fatwa DSN No:17/DSNMUI/IX/2000 Tentang Sanksi Atas Nasabah Mampu Yang Menunda-Nunda. Namun pengelolaan ta'zir pada masa sekarang khususnya yang dilaksanakan di perbankan syariah belum memiliki ketentuan pengelolaan yang jelas. Berdasarkan hal di atas, maka penulis mencoba menelaah konsep pengelolaan dana ta'zir yang dilakukan pada masa lampau, sehingga dapat dijadikan acuan atau analisa perbandingan dengan pengelolaan dana ta'zir yang dilakukan oleh bank syariah pada masa sekarang. Dalam hal ini,l informasi mengenai penerapan sistem keuangan Islam dapat diketahui dengan cara meneliti konsep-konsep ekonomi Islam yang ditinggalkan oleh para ulama dan para 
ahli ekonomi Islam masa lalu melalui karya-karya literaturnya. Di sisi lain, pembahasan mengenai literasi masa lalu menarik juga untuk dilakukan karena justru dalam naskah-naskah tersebut terkandung berbagai nilai dan konsep yang relevan untuk dijadikan solusi pada permasalahan masa sekarang. Naskah-naskah literasi dalam dunia Sejarah Peradaban Islam juga menarik kembali untuk dikejai dan ditelaah kandungannya. Karena tidak menutup kemungkinan bahwa nilai-nilai maupun teori yang terkandung dalam naskah tersebut mampu menjelaskan problematika permasalahan perdaban di masyarakat yang terjadi pada masa sekarang khususnya dalam kajian bidang hukum ekonomi Islam.

Salah satu naskah yang membahas persoalan keuangan publik dalam Islam klasik yaitu naskah Al Amwal karya Abu Ubaid Al-Qasim bin Sallam bin Abdillah Al-Adib AlFaqih Al-Muhadits (157 H/774 M - 224 H/838 M) atau yang lebih dikenal dengan sebutan Abu Ubaid, seorang ulama Islam yang produktif.1 Pada kajian kitab Al Amwal karya Abu Ubaid, dikatakan bahwa sumber keuangan publik terdiri dari sumber-sumber dana berupa zakat, pajak (kharaj, jizyah dan ursy) serta shadaqah yang bersifat umum atau khusus seperti ghanimah, khumus dan dana ta'zir yang masuk ke dalam kategori fai.2 Adapun pengelolaan dana dari hasil ta'zir tersebut sebagaimana sumber dana atau sumber keuangan publik yang berasal dari shadaqah umum dan khusus meliputi ghanimah, khumus dan fai, dialokasikan bagi kepentingan publik dan infrastruktur.3

BRI Syariah KCI Citarum Kota Bandung sebagai salah satu bank syarah juga menerapkan atuaran denda (ta'zir) bagi nasabah pembiayaan yang melakukan wanprestasi. Dalam hal ini, pengelolaan dana ta'zir yang dilakukan di BRI Syariah masih belum jelas karena dananya tumpang tindih atau bercampur dengan dana Zakat Infaq Shadaqah (ZIS). Sehingga hal ini menimbulkan indikasi adanya tumpang tindih pengelolaan dana ta'zir tersebut dengan dana zakat infaq shadaqah yang telah memiliki alokasi penggunaan yang sudah diatur peruntukkannya yaitu pada kegiatan CSR BRI Syariah. Dengan demikian, hal tersebut menarik untuk dikaji dari sisi akademik dengan mengkaji relevansi dari pengelolaan dana ta'zir di BRI Syariah dengan pengelolaan ta'zir menurut Abu Ubaid yang terkandung dalam kitab Al Amwal yang merupakan sebuah mahakarya tentang ekonomi yang dibuat oleh Abu Ubaid. Kitab Al-Amwal secara komprehensif membahas tentang sistem keuangan publik Islam termasuk dana ta'zir yang masuk ke dalam kategori fai.

\section{B. Tujuan Penelitan}

Tujuan penelitian ini untuk memperoleh jawaban dari permasalahan yang telah dirumuskan. Adapun tujuan dalam penelitian ini adalah antara lain :

1. Untuk mengetahui konsep pengelolaan dana ta'zir menurut Abu Ubaid yang terkandung dalam Kitab Al Amwal.

2. Untuk mengetahui pelaksanaan pengelolaan denda ta'zir dalam penyaluran produk pembiayaan di BRI Syariah KCI Citarum Kota Bandung.

3. Untuk mengetahui tinjauan konsep kebijakan keuangan publik menurut Abu Ubaid Dalam Kitab Al Amwal terhadap pengelolaan dana ta'zir di BRI Syariah KCI Citarum Kota Bandung.

\section{LANDASAN TEORI}

\section{A. Pengertian Ta'zir}

Kata ta'zir berakar dari kata 'azzara yang secara arti kata mengandung arti membantu, membantu menghindarkan dari suatu yang tidak menyenangkan; membantu melepaskan diri dari kejahatan; membantu keluar dari kesulitan.4 Ta'zir merupakan sesuatu yang baru, mengingat dalam terma-terma fiqh klasik, hal itu belum diperbincangkan secara jelas, baik dalam tataran teks mupun konteks. Memahami kedua terma diatas menuntut kita untuk lebih cermat melihat persoalan tersebut ke dalam produk fiqh kontemporer yang lahir akibat proses modernisasi. Dalam prosesnya, fiqh berawal sebagai produk yang lahir dan bersinggungan dengan individu (perseorangan) sehingga cakupannya hanya sebatas wilayah privat dan tidak menyentuh ranah kelompok atau lembaga (publik).

Ketika pengaturan mengenai dasar-dasar mua'amalah hanya dalam lingkup personal maka unsur-unsur spritual dan ruhaniyah lebih mudah untuk diterapkan dimasa-masa awal Islam. Disamping itu, ajaran-ajaran ketuhanan yang dibawa nabi Muhammad SAW sebagai misi utama dalam segenap aspek kehidupan termasuk segi mua'amalah selalu mewarnai sikap para sahabat dan pengikutnya, hal ini berpengaruh pada sikap kepatuhan dan ketaatan kaum muslimin waktu itu untuk menerapkan spirit Islam di bidang ekonomi. Pelarangan unsur riba, maisir, judi, gharar dan dzulm dalam bermua'amalah menjadi patokan dasar yang harus dihindari dalam setiap transaksi.

Begitu juga pengaturan tentang Ta'zir bagi pelaku bisnis, saat itu masih belum terdokumentasikan secara spesifik baik pada tataran normatif (teks fiqh) maupun tataran empiris (praktik dilapangan).5 Namun, karena interaksi dan pergeseran budaya yang berkembang, maka seluruh transaksi bisnis itu menjadi luas, tidak sebatas 
lingkup individu saja, tapi sudah menyentuh ranah publik bahkan antar negara. Akibatnya banyak muncul penyimpangan terhadap aturan-aturan yang bersifat primordial tersebut, termasuk di dalamnya tentang kelalaian (wanprestasi) dan kurang disiplinnya nasabah untuk menunaikan kewajibannya dalam pembayaran hutang. Pelanggaran ini muncul karena lemahnya sistem dan control dalam menjalankan transaksi keuangan. Oleh karena itu transaksi keuangan modern dalam hal ini memberlakukan sistem denda (Ta'zir) untuk meminimalisir pelanggaran tersebut.

\section{B. Pengelolaan Dana Ta'zir Menurut Abu Ubaid dalam Kitab Al Amwal}

Abu ubaid bernama lengkap Al-Qosim bin sallam bin Miskin bin Zaid Al-Harawi Al-Hazadi Al-Baghdadi. Ia lahir pada tahun $150 \mathrm{H}$ di kota Harrah Khurasan, sebelah barat laut Afganistan.6 Beliau pertama kali belajar di kota asalnya, lalu pada usia 20-an pergi ke Kufah, Basrah, dan Bagdad untuk belajar tata bahasa arab, qira'ah, tafsir, hadis, dan fikih. Pada tahun 192 H, Tsabit Ibn Nasr Ibn Malik ( Gubernur Thugur ) dimasa pemerintahan Kholifah Harun Al-Rasid, mengangkat Abu Ubaid menjadi qodi (hakim). Beliau juga merupakan seorang ahli Hadits dan ahli Fuqoha yang terkemuka dimasa hidupnya. Beliau wafat di Makkah pada tahun 224 H.7

Karya Abu Ubaid khususnya dalam pemikiran dan pandangannya terhadap kehidupan sosial ekonomi dengan corak peradaban Islam dituangkan dalam Kitab Al Amwal. Semua konsep pemikiran dan pandangannya tersebut dituangkan dalam Al Amwal, sehingga Kitab Al Amwal merupakan satu-satunya karya Abu Ubain namun syarat nilai dan kaya akan khasazah keilmuan khususnya terkait masalah-masalah sosial dan ekonomi. Salah satu kandungan dalam kitab Al Amwal tersebut adalah membahas mengenai pengelolaan keuangan public termasuk yang bersumber dari tazir.

Ta'zir menurut Abu Ubaid termasuk pemasukan bagi kas negara yang tergolong ke dalam fai diambil secara paksa dari pihak yang melakukan pelanggaran hukum (denda). Meskipun sifatnya memaksa, ta'zir berbeda dengan zakat karena zakat telah memiliki pos tersendiri. Dalam Kitab Al Amwal, Abu Ubaid menguraikan bahwa Zakat sebagai institusi keuangan publik, di mana pemerintah bertanggung-jawab atasnya telah mengalami degradasi. Zakat ini dibayarkan kepada Nabi Muhammad SAW atau kepada orang yang beliau utus. Setelah beliau wafat, zakat dibayarkan kepada Abu Bakar atau kepada orang yang diutusnya. Kemudian, kepada Umar bin Khattab atau kepada orang yang diutusnya. Lalu, pembayaran zakat setelah wafatnya Umar bin Khattab dibayarkan kepada khalifat penggantinya Ustman bin Affan atau kepada orang yang diutusnya. Dengan demikian, maka zakat yang merupakan kewajiban pemerintah untuk mengurus dan mendistribusikannya kepada masyarakat.

Ta'zir digolongkan kepada pendapatan non periodik sebagaimana bagian dari instrumen fai seperti ursy. Kemudian alokasi penggunaan dana ta'zir juga tidak jauh berbeda dengan alokasi sumber keuangan dari fai secara umum. Alokasi fai digunakan untuk Nafaqah al Daulah, yaitu padanan dari istilah anggaran belanja Negara. Dalam hal ini, Abu Ubaid menguraikan pandangannya pada kitab Al Amwal bab tersendiri mengenai persamaan manusia dalam kekayaan publik. Mengenai hal ini, diantaranya adalah komentar Abu Bakar ra, ketika datang kepadanya harta (fa'i/ghanimah) ia menjadikan (bagian) manusia sama, dan berkata: "Aku menginginkan terhindar dari meminta-minta dan memurnikan perjuangan (jihad) ku bersama Rasulullah saw, kelebihan mereka adalah di sisi Allah, adapun dalam hidup ini persamaan adalah hal yang baik". Dalam pendistribusian pengeluaran dari penerimaan khumus (khumus ghanimah, khumus barang tambang dan rikaz serta khumus lainnya) adalah ketentuan dari Rasulullah saw dan pendistribusiannya kapan dan untuk siapa tentu juga dengan ketentuan Rasulullah. Karena dana-dana publik merupakan kekayaan publik, maka dialokasikan untuk kesejahteraan publik seperti kesejahteraan anak-anak, korban bencana, santunan dan lainnya.

\section{Hasil PENELITIAN DAN ANALISA PEMBAhasan}

Penerapan ta'zir di BRI Syariah KCI Citarum Kota Bandung diberlakukan kepada nasabah yang melakukan pelanggaran yaitu keterlambatan dalam pembayaran piutang pembiayaan. Dalam konteks ta'zir sebagai bentuk sanksi berupa denda menurut Abu Ubaid, penerapan ta'zir yang dilakukan BRI Syariah sudah sesuai karana ta'zir dalam kitab Al Amwaal yang disusun Abu Ubaid merupakan bentuk sanksi atau denda pada pelanggran yang bersifat keperdataan. Dalam hal ini, penulis menilai bahwa hubungan nasabah dengan BRI Syariah termasuk ke dalam masalah keperdataan karena hubungan tersebut terjalin akibat perjanjian akad pembiayaan antara pihak nasabah dengan BRI Syariah. Dengan demikian, maka dapat dikatakan bahwa secara konsptual, penerapan ta'zir di BRI Syariah sesuai dengan konsep penerapan ta'zir menurut Abu Ubaid dalam kitab Al Amwal. Akan tetapi, dalam pengalokasian dana ta'zir, terdapat dimensi perbedaan antara kebijakan yang dilakukan BRI Syariah dengan konsep Abu Ubaid dalam Kitab Al Amwaal terkait alokasi dana ta'zir tersebut.

Secara umum pengelolaan ta'zir di BRI Syariah KCI Citarum dilakokasikan ke dalam dana sosial yang diperuntukan untuk kegiatan sosial. Seperti: pembelian mobil kesehatan keliling, vaksinasi anak-anak, khitanan masal. Dalam hal ini, pengalokasian dana ta'zir di BRI Syariah setidaknya ada yang telah sesuai dengan alokasi dana ta'zir menurut Abu Ubaid dalam kitab al Amwaal yaitu disalurkan pada golongan yatama (anak-anak yatim 
piatu) dengan bentuk bantuan seperti khitanan masal dan vaksinasi. Namun demikian, dalam kitab Al Amwaal disebutkan bahwa porsi alokasi bagi yatama adalah $20 \%$ dari $1 / 5$ total pendapatan ta'zir, sedangkan pihak BRI Syariah tidak menyebutkan secara rinci berapa persen porsi yang disalurkan kepada anak-anak yatim dari pendapatan tazir yang didapatkan BRI Syariah.

Selanjutnya dalam alokasi dana sosial pada alokasi dana ta'zir, BRI Syariah tidak menyebutkan secara spesifik bentuk kegiatan sosial dalam program CSR yang dilakukan. Jika dilihat dari program CSR yang dilakukan BRI Syariah, pada umumnya kegiatan CSR tersebut dialokasikan pada masyarakat dalam bentuk kegiatan sosial, bantuan material serta hal-hal yang bersifat bantuan individu. Hal ini berbeda dengan ketentuan alokasi ta'zir menurut Abu Ubaid yang porsi besarnya dialokasikan kepada sektor fasilitas kepentingan public seperti Jalan, jembatan, Sekolah, Taman Kota, Perpustakaan Umum dan fasilitas tempat ibadah. Namun dalam hal ini, kegiatan CSR yang dilakukan BRI Syariah dengan sumber dana dari ta'zir terdapat juga alokasi untuk pembangunan masjid atau sarana ibadah. Hal ini sejalan dengan konsep alokasi dana tazir menurut $\mathrm{Abu}$ Ubai yang diantaranya diperuntukan untuk pembangunan tempat ibadah yang termasuk ke dalam fasilitas publik.

\section{KESIMPULAN}

Konsep pengelolaan dana ta'zir menurut Abu Ubaid Yang Terkandung Dalam Kitab Al Amwal dialokasikan kepada keuangan negara untuk kemaslahatan kaum Muslimin (fasilitas umum, infrastruktur dan dana pendidikan). Hal ini terjadi ketika bentuk hukuman ta'zir diputuskan dalam bentuk denda atau pemungutan harta secara terpaksa dari sesorang yang melakukan pelanggaran atau kesalahan dalam konteks hukum.

Pelaksanaan pengelolaan denda ta'zir dalam penyaluran produk pembiayaan di BRI Syariah KCI Citarum Kota Bandung dimasukan ke dalam dana sosial yang diperuntukan untuk kegiatan sosial. Seperti: pembelian mobil kesehatan keliling, vaksinasi anak-anak, khitanan masal. Dan BRI Syariah juga bekerja sama dengan baznas dan lembaga amil zakat swasta yang bekerjasama dengan BRI Syariah.

Pengelolaan dana ta'zir di BRI Syarriah KCI Citarum Bandung belum sepenuhnya sesuai dengan konsep pengelolaan dana tazir menurut Abu Ubaid dalam kitab Al Amwaal. Dalam hal ini, kesusiaan alokasi dana ta'zir terdapat pada pelaksanaan penyaluran atau santunan bagi anak-anak yatim piatu yang dilakukan BRI Syariah pada program CSR dan bantuan dana dalam pembangunan masjid sebagai sarana publik. Namun pihak BRI Syariah tidak merinci secara jelas porsi persentase alokasi dana tazir kepada fasilitas public dan santunan anak yatim sebagaimana yang disebutkan dalam kitab Al Amwal yaitu $1 / 5$ untuk fasilitas publik dan $20 \%$ dari $4 / 5$ untuk sntunan anak yatim.

\section{DAFTAR PUSTAKA}

[1] Abd al-Wahhab Khalaf, al-Siyasah al-Syar'iyyah, Al-Munirah : Matba"eah al-Taqaddum, 1977.

[2] Abu 'Ubaid pada kitab al-Amwal, Abu Ubaid Al-Qasim bin Sallam, Kitab al-Amwal Beirut: Dar al Fikr, 1989.

[3] Abu 'Ubaid al-Qasim, al-Amwal: Ensiklopedia Keuangan Publik, ter. Setiawan Budi Utomo, Jakarta : Gema Insani, 2006.

[4] Adiwarman Karim Azwar, Bank Islam dan Analisis Keungan, cet.VIII, Jakarta: Rajagrafindo Persada, 2013.

[5] Adiwarman Karim Azwar, Ekonomi Islam:Suatu Kajian Ekonomi Makro. Jakarta : Karim Business Consulting, 2001.

[6] Adiwarman Azwar Karim, Sejarah Pemikiran Ekonomi Islam,Jakarta : PT Raja Grafindo, 2007.

[7] Amir Syarifuddin, Garis-Garis Besar Fiqih, cet.I, Bogor : Prenada Media, 2003.

[8] Ani Fitriyani, Pengaruh Pengeanaan Ta'zir Terhadap Tingkat NPF (Skripsi S.1 Fakultas Syariah dan Hukum, Universitas Islam Syarif Hidayatullah, Jakarta 2012.

[9] Muhammad Natsir, Metode Penelitian, CV Bumi Aksara, Jakarta, 2000 .

[10] Nur Chamid, Jejak Langkah Sejarah Pemikiran Ekonomi Islam, Pustaka Azzam, Jakarta, 2011.

[11] Pusat Pengkajian dan Pengembangan Ekonomi Islam (P3EI) dan UII, Ekonomi Islam, Yogyakarta : UII Press, 2006.

[12] Uus Rustiman, Naskah Al Amwal ; Suntingan Teks \& Kajian Pemikiran Ekonomi Islam Abu Ubaid Tentang Keuangan Publik, Desertasi, Universitas Padjadjaran, 2017.

[13] Wahbah Azzuhaili, Fiqih Islam Wa Adillatuhu, jilid V, cet.X, Damaskus: Darul Fikr, 2007.

[14] Zainul Arifin, Dasar-Dasar Menajemen bank Syariah,cet.IV, Pustaka Alvabet, Jakarta, 2006. 